\title{
Analysis of the Exhaust Emissions of Toxic Compounds from a Special Purpose Rail Machine PŁT-500 During Profiling the Ballast Cess
}

\author{
Paweł Daszkiewicz , Maciej Andrzejewski ${ }^{1}$, Patryk Urbański1 ${ }^{*}$, Aleksandra Woch", \\ Natalia Stefańska ${ }^{1}$ \\ 1 Łukasiewicz Research Network-Rail Vehicles Institute „TABOR”, ul. Warszawska 181, 61-055 Poznań, Poland \\ * Corresponding author's e-mail: patryk.urbanski@tabor.com.pl
}

\begin{abstract}
Track works typically require the use of special-purpose rail machines, in which the main source of propulsion includes high-power compression ignition engines. Reliance on these types of engines, which are characterized by a significant degree of wear and tear, relates to relatively high specific fuel consumption and the exhaust emissions of toxic compounds. Using such rail machines to perform modernization and repair works has a negative impact on the natural environment. The article presents test results of toxic compounds exhaust emissions as measured from a special purpose rail machine. The tested vehicle was a machine designed for profiling the ballast cess labeled as PŁT-500. The machine was classified as NRMM (Non Road Mobile Machinery) as well as used for profiling and cleaning the cess. A PEMS (Portable Emissions Measurement System) type apparatus was used for the emissions measurement. This made it possible to measure the exhaust emissions as RDE (Real Driving Emissions) of toxic compounds from the machine under real operating conditions. The obtained test results include the measured exhaust emissions of gaseous compounds: $\mathrm{CO}, \mathrm{CO}_{2}, \mathrm{HC}$ and $\mathrm{NOx}$ as well as the vehicle fuel consumption while performing its track works.
\end{abstract}

Keywords: exhaust emission, non road mobile machinery, real driving emissions, special purpose rail machine, PŁT-500 machine, railway subgrader

\section{INTRODUCTION}

The technical condition of the railway infrastructure and the rolling stock is of great significance for the effective functioning of the railway system and is also important for maintaining safety and reducing the risks of unwanted events occurring. In order to improve the quality of rail vehicles in operation, more advanced systems for the subassemblies condition assessment, including wheels [1], axles, [2, 3] and bearings [4], are being developed, which are designed with the ability to detect the elements reaching the limit values of their expected operating condition. The systems are also used to assess the condition of the railway line itself $[5,6]$, which is essential for the effective operation of this mode of transport. The resulting solutions allow for estimating the optimal resources and determining corrective actions, owing to which it becomes possible to manage the railway infrastructure and rolling stock more efficiently [7].

Poland ranks fourth in Europe in terms of the total railway network length, but a significant share of the Polish lines requires modernization. The technical condition of the railway track is divided into four categories, i.e.: good (requiring only maintenance, no restrictions in use), satisfactory (requiring replacement of pavement elements up to $30 \%$, minor limitations in use), unsatisfactory (the need for comprehensive replacement, significant restrictions) and bad (suspension of rail traffic). In 2019 , over $60 \%$ of railway lines in Poland were classified as being in good technical condition. In the period 2015-2019, the percentage of lines in good technical condition gradually 
increased (Figure 1). The total length of tracks on which the speed limit was lowered has decreased. In 2019, the speed limit was lowered for 367 kilometers of track length, while for 1,249 kilometers it was increased (Figure 2) [8]. This means that, as a result, the technical condition of the rail lines improved in the case of 882 kilometers of track.

The improvement of the railway infrastructure condition is related to the continuous track repair works, such as: maintenance, repairs (current, main, emergency) and modernization. Major repairs include, among others: adjustment of the track position, replacement of individual railway track elements, re-profiling of rails, cleaning and refilling of the ballast, profiling of the track cess (Table 1). Specialized track machines designed for specific tasks are used to perform the tasks listed [9].
However, it should be remembered that the rolling stock in Poland is quite old. According to the data of the Office of Rail Transport, a significant part of it in Poland is 40 years old or more [11]. This group of outdated rolling stock also includes specialist track machines, which, due to the nature of the work performed and non-dependence on electric traction, are normally equipped with internal combustion engines. To a large extent, these are drive units, many of them manufactured in the years 1970-1980, i.e. during the period of very liberal or non-binding exhaust emission norms for rail vehicles [12]. The significant age of vehicles and, consequently, a high degree of their wear and tear, contribute to the increased environmental harmfulness of their operation.

Despite the clear advantages of an internal combustion engine, its main disadvantage is the

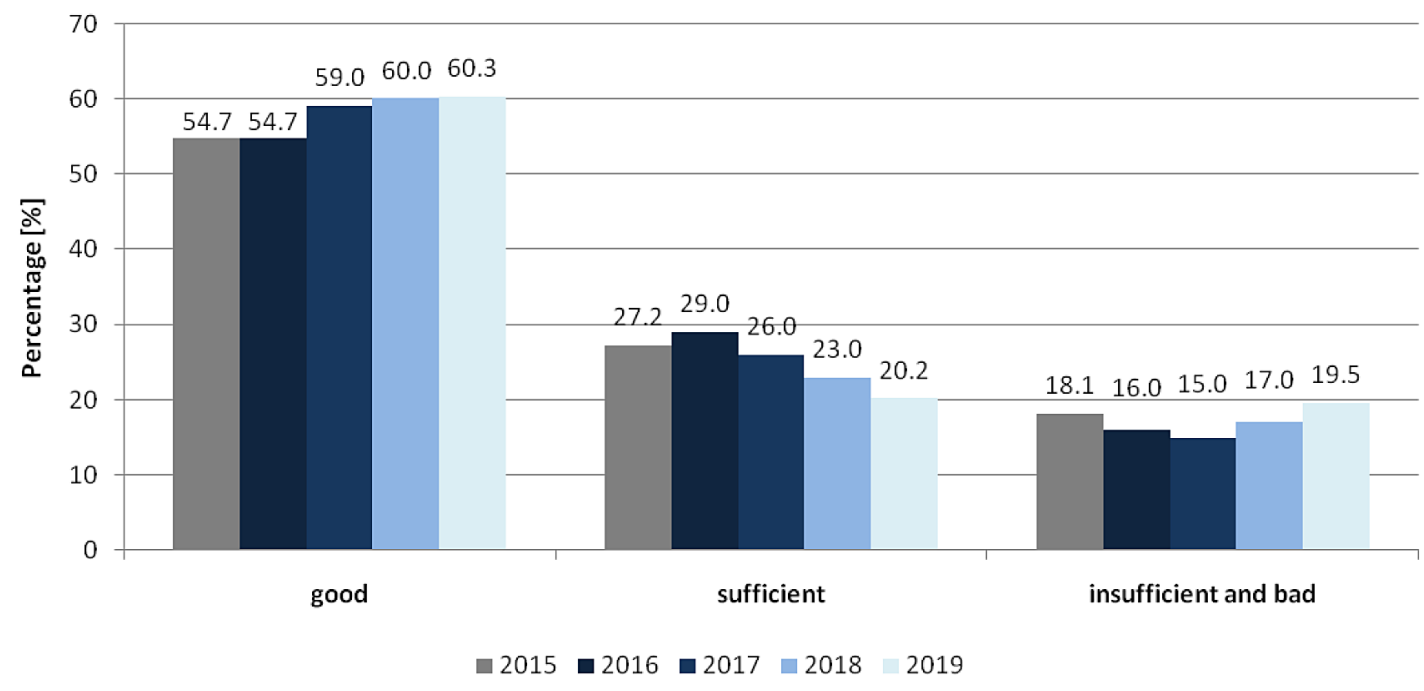

Figure 1. Assessment of the technical condition of the PKP PLK railway infrastructure in the period 2015-2019 [8]

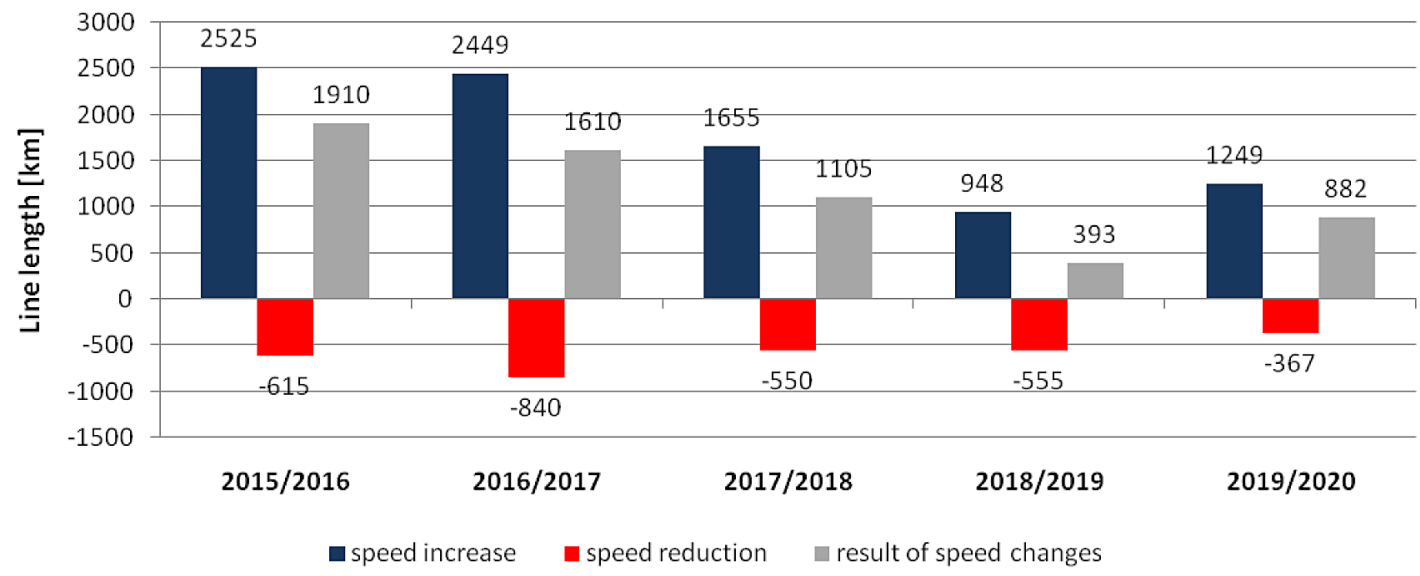

Figure 2. Speed limit changes on PKP PLK lines in the period 2015-2019 [8] 
Table 1. Classification of repairs by type along with a detailed breakdown [10]

\begin{tabular}{|c|c|c|}
\hline \multicolumn{3}{|r|}{ Repair works by type } \\
\hline & Type & Details \\
\hline \multicolumn{2}{|l|}{ Maintenance } & $\begin{array}{l}\text { - securing cracks in rails, } \\
\text { - replacement of damaged and missing connectors, } \\
\text { - tightening bolts and screws, } \\
\text { - improvement of track gauge, } \\
\text { - removal of vegetation, } \\
\text { - tamping of individual sleepers and switches, } \\
\text { - filling the ballast, } \\
\text { - lubrication of switches. }\end{array}$ \\
\hline \multirow[t]{3}{*}{ Renovations } & Ongoing repairs & $\begin{array}{l}\text { - adjustment of the track position in the horizontal and vertical axis, } \\
\text { - replacement of individual elements of the railway track, } \\
\text { - full repair of a cracked rail, } \\
\text { - maintenance of the steel elements of the rail surface, } \\
\text { - replacement of switch parts, } \\
\text { - regulation of longitudinal forces in continuous welded rail, } \\
\text { - re-profiling of the rails, } \\
\text { - adjustment of sliding rails and rail spacing, } \\
\text { - cleaning and replenishing the ballast, } \\
\text { - profiling of the track cess. }\end{array}$ \\
\hline & Major repairs & $\begin{array}{l}\text { - comprehensive (continuous and complete replacement of all surface elements), } \\
\text { - non-comprehensive (continuous replacement of one or two pavement elements). }\end{array}$ \\
\hline & Emergency repairs & - \\
\hline \multicolumn{2}{|l|}{ Modernization } & $\begin{array}{l}\text { - improvement investments, } \\
\text { - modernization investments. }\end{array}$ \\
\hline
\end{tabular}

emission of harmful exhaust compounds, which has a negative impact on the natural environment. Thus, many institutions have undertaken the task of measuring and analyzing the exhaust emissions from various means of transport. This type of research is characterized by high complexity, among others due to the difficulty of assessing the exhaust emissions during the drive system operation [13]. In addition, many legislative tests do not take into account the engines working under real operating conditions, which translates into less reliable test results. Therefore, Real Driving Emission (RDE) studies are conducted, which take into account a wider engine operating range [14-18]. Additionally, in order to reduce the exhaust emissions and fuel consumption in transport, research is conducted on alternative fuels and propulsion sources, which leads to innovation in the applications of fuel cells [19] as well as increase the number and diversity of available hybrid solutions [20], including those using ultracapacitors, all of which also applies to rail vehicles [21].

The total emission of harmful gaseous compounds from rail vehicles is not limited only to the emissions from the engine operation. It should also take into account the losses of hydrocarbons and volatile organic compounds (fuels and lubricants) from the fuel supply systems, lubricants applied to exposed parts and the refueling process, as well as the wear of friction elements (mainly the brake system) and resuspension of track dust (Figure 3). This article presents the scientific procedure and test results of the study on the measurement of exhaust emissions and fuel consumption from the vehicle drive system, which is the largest contributor to the total emissions produced by a rail vehicle.

\section{METHODS}

Many years of exploitation cause the railroads to deteriorate, with the cess of the railway tracks tending to overgrow with vegetation. Additionally, the erosion of the crushed stone causes the cess width to decrease. It is also common for the appropriate inclinations towards the ditches or embankment slopes to not be properly maintained. As a consequence, high wear and adverse climatic conditions [22] lead to a reduction in the drainage of rainwater from the railroad, which causes the strength of the track bed to deteriorate significantly. At that point, it becomes necessary to lower (flatten) the ballast cess, as well as shape and clean the ballast from in front of the sleepers. In Poland, the machine that performs these activities is the PŁT500 railway subgrader.

The tested machine was a vehicle from the NRMM (Non-Road Mobile Machinery) group. The PŁT500 railway subgrader is a self-propelled rail vehicle powered by a $200 \mathrm{~kW}$ Wola Henschel 


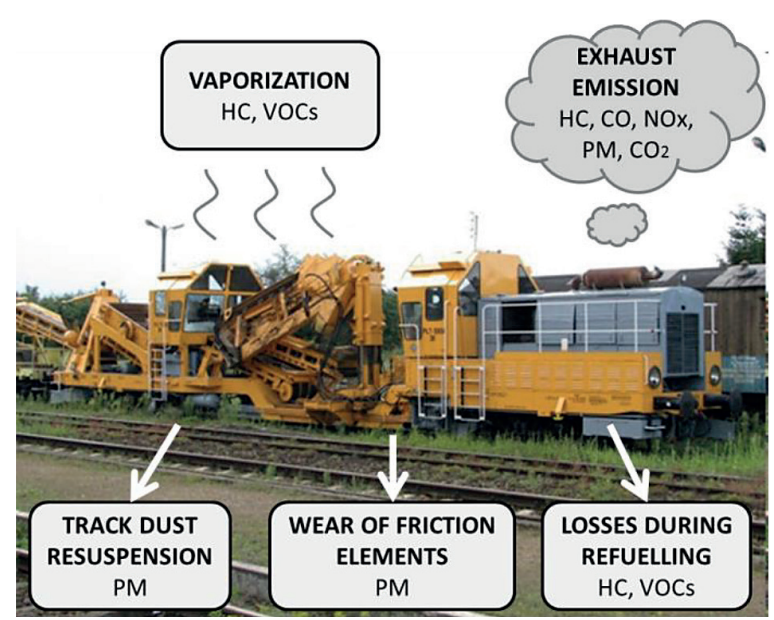

Figure 3. Pollutants emission from rail vehicles

H12 internal combustion engine. The vehicle was designed to lower the track cess to a depth of $1 \mathrm{~m}$ below the rail head and to a width of $1.5 \mathrm{~m}$. The maximum range of the profiling machine reached up to $2.9 \mathrm{~m}$ from the track axis. The ballast cleaning technology was developed and introduced in the 1970s. The ballast on the railroad is cleared by a set of track machines consisting of the main ballast cleaning machine OT 400, two PŁT 500 railway subgrader machines and a train for transporting the filtered material PTO 200. Figure 4 shows a schematic of the ballast cleaning and profiling process for the track cess.

Material is extracted from the ballast cess by means of a selector chain moving in the ballast bed. The soil and contaminated crushed stone are transported via a conveyor belt to the sieves in the screening units. The cleaned ballast is sent to the track through a chute, while any contamination is transported to the self-unloading wagons (Figure 5). In some cases, the filtered out waste material is dumped onto the slopes of the embankment or the ditch. Such an operation is only permitted if the rejected contaminant material is used to strengthen the soil structure or to widen the track.

The aim of the study was to assess the fuel consumption and the exhaust emission of harmful compounds from the internal combustion engine of the tested rail machine under real operating conditions (RDE). The measurements were performed using mobile measuring equipment belonging to the PEMS category (Portable Emission Measurement System). The measuring equipment included the analyzers for determining the concentration of gaseous exhaust components emitted by the engine, such as: Semtech-DS and the TESTO 360 device with software. It was also necessary to use an exhaust gas flowmeter in order to properly determine the exhaust emission values from the drive test (Figure 6). All presented measurements were performed on a severalkilometer section of the modernized railway line between Poznań and Gniezno.

The track maintenance work performed by the ballast profiler consisted of several types of activities, which differed from each other in terms of their characteristics, operating conditions and the time duration. Table 2 and Figure 7 show a breakdown of the activities performed by the PŁT 500 railway subgrader during a standard working day. In addition to the work related to the profiling and cleaning of the track ballast, the machine traveled between work points, which were also included in the test results. The activities included in the tests also comprise the so-called cold engine start for rolling stock, which lasted 1300 seconds. The operating conditions were divided based on the percentage load of the drive unit. The conditions were classified as: very light (0-20\%); light (21-40\%); moderately severe (41-60\%), severe

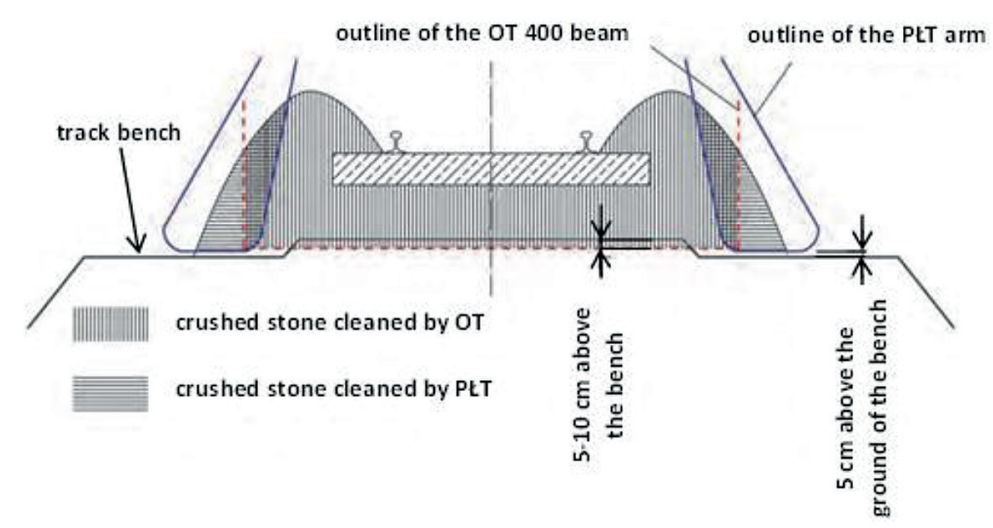

Figure 4. Schematic of the ballast cess cleaning and profiling process done by the OT 400 and PŁT-500 units [10] 


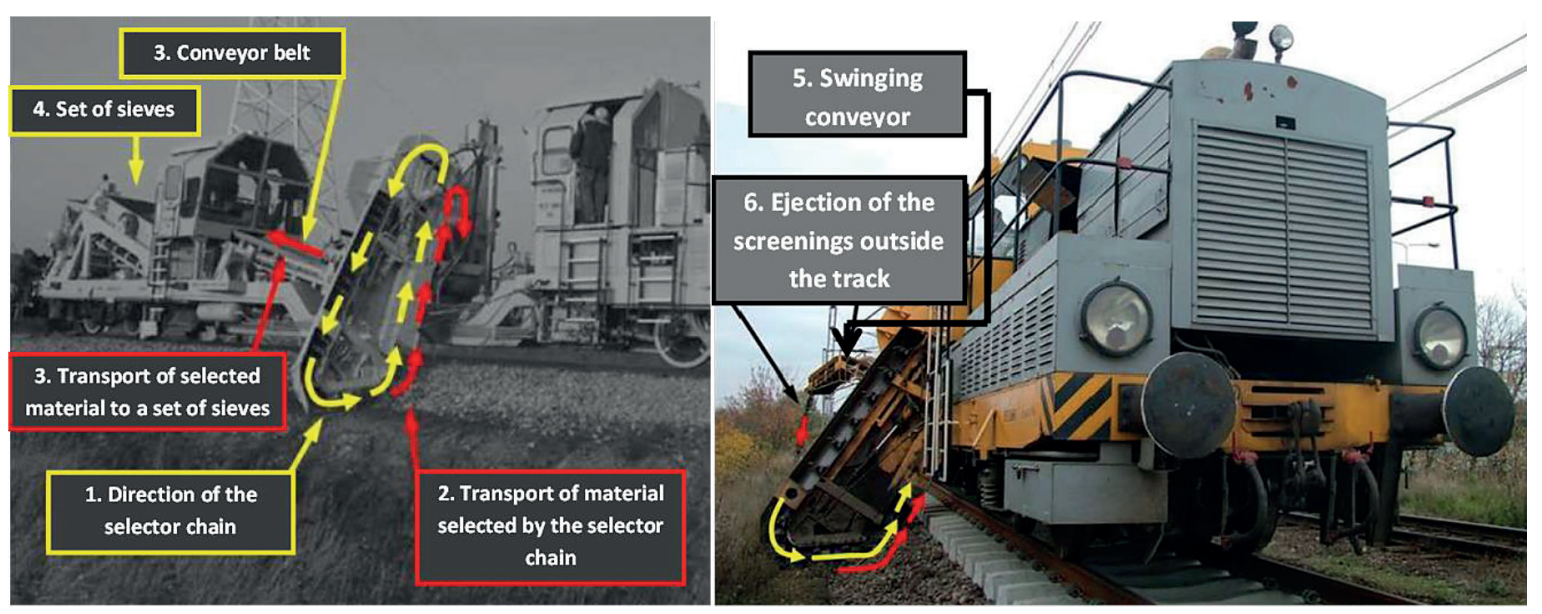

Figure 5. The PŁT-500 railway subgrader principles of operation [23]

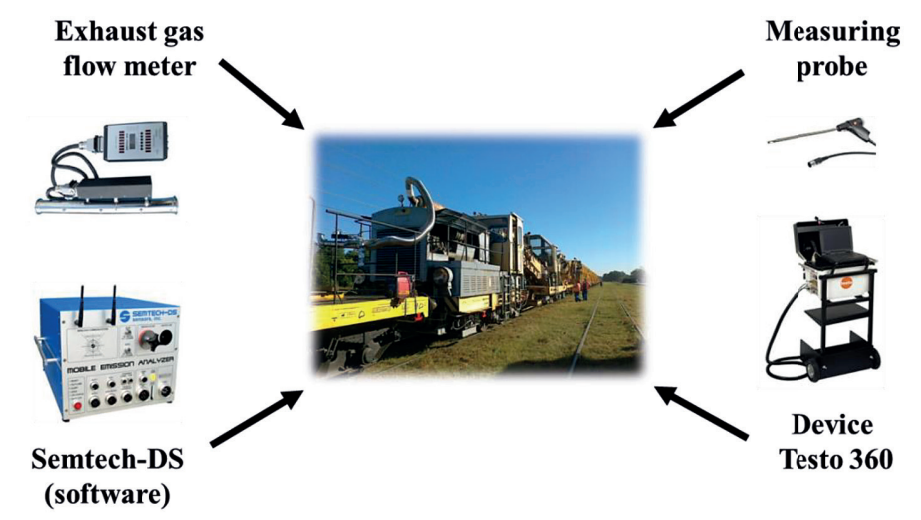

Figure 6. Measuring apparatus installed on the tested rail machine

(61-80\%) and very severe (81-100\%). Moderately severe engine load was most prevalent, which included the lowering of the track rails in sections covered with grassy vegetation. The total amount of time the profiling machine was operational reached about 3 hours and it consisted of individual jobs the share of which in the total work time was shown in Figure 8.

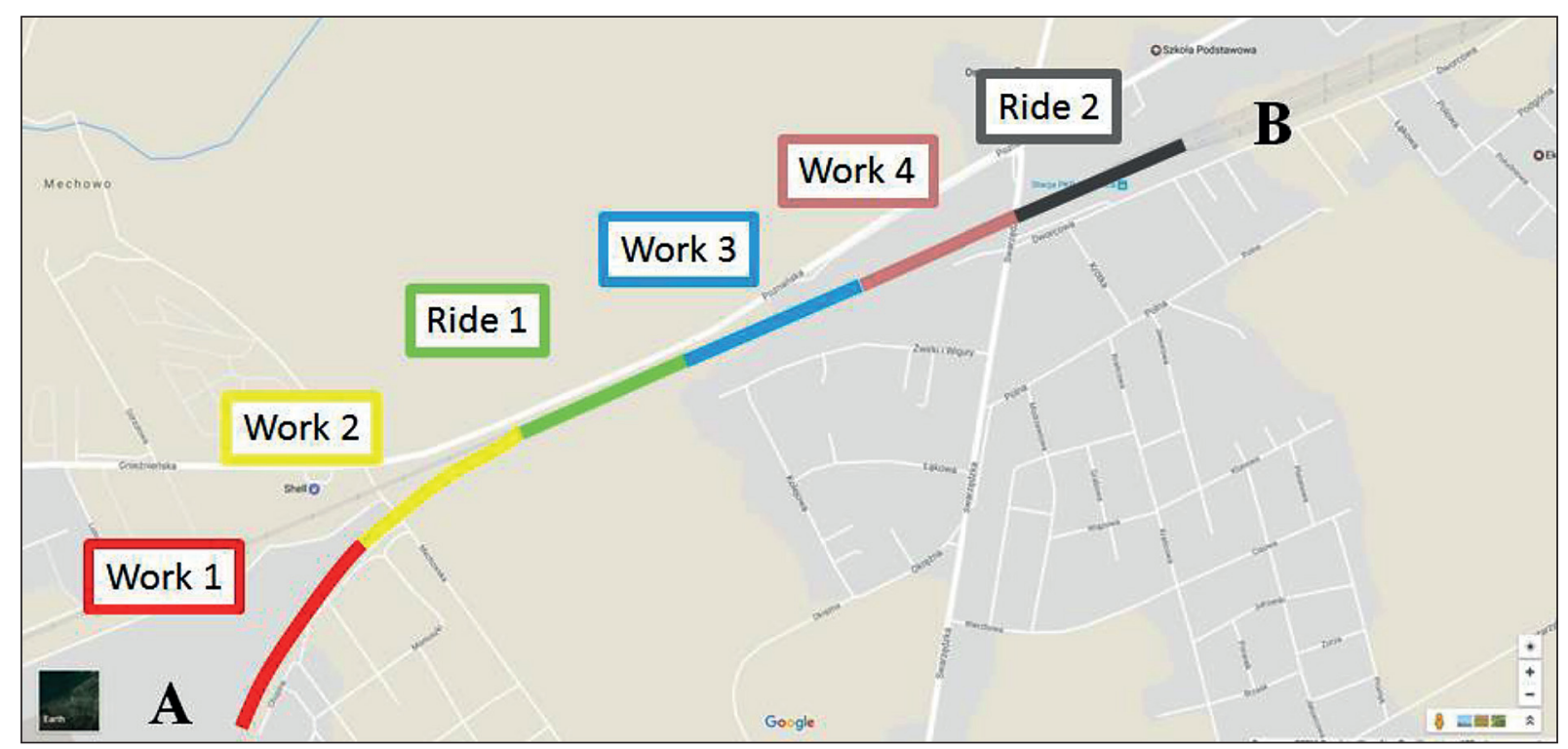

Figure 7. Test rail section location for the PŁT-500 railway subgrader machine tests [24] 
Table 2. The nature of the activities performed with the use of the PŁT-500 railway subgrader machine

\begin{tabular}{|c|c|c|c|c|}
\hline No. & Activity & Duration [s] & Operating conditions [-] & Notes \\
\hline 1 & Starting & 1300 & Very light & $\begin{array}{l}\text { Starting the engine and heating it up until a set thermal state } \\
\text { is obtained - cold start }\end{array}$ \\
\hline 2 & Stoppage & 325 & Light & The hydraulic drive system of the machine is turned on \\
\hline 3 & Work 1 & 1280 & Very severe & $\begin{array}{l}\text { The track cess was covered with sporadic small deciduous } \\
\text { and coniferous trees }\end{array}$ \\
\hline 4 & Work 2 & 450 & Severe & The track cess was partially covered with larger grasses \\
\hline 5 & Ride 1 & 585 & Very light & $\begin{array}{l}\text { The hydraulic drive system of the machine has been turned } \\
\text { off; powered by its own engine unit during the journey }\end{array}$ \\
\hline 6 & Work 3 & 2215 & Moderately severe & Cess area not covered with vegetation \\
\hline 7 & Work 4 & 4400 & Moderately severe & Cess area not covered with vegetation \\
\hline 8 & Ride 2 & 330 & Very light & $\begin{array}{l}\text { The hydraulic drive system of the machine was turned off; } \\
\text { shunted by another vehicle during the final section; return to } \\
\text { the rolling stock base - pulled by a motorized MPD platform } \\
\text { with profiler engine idling }\end{array}$ \\
\hline
\end{tabular}

\section{RESULTS}

The exhaust emission test results cover eight types of activities performed by the tested ballast profiler. The first operation was characterized by the highest $\mathrm{CO}$ emission, when the track cess was covered with small deciduous and coniferous trees (Figure 9). At that time, the operating conditions were described as very severe. The second highest value was recorded when the machine was stopped with the hydraulic system on. The works that were labeled with numbers 2, 3 and 4 have similar $\mathrm{CO}$ emission values, oscillating around $75 \mathrm{~g} / \mathrm{h}$. The lowest emission was registered during engine start and return to the rolling stock base.

In terms of hydrocarbons emissions, the second work section showed the highest hourly emission, when the track cess was covered with larger grasses (heavy conditions) (Figure 10). The exhaust emission of $\mathrm{HC}$ in this work section was more than twice as high $(66.1 \mathrm{~g} / \mathrm{h})$ as the second highest value $(35.5 \mathrm{~g} / \mathrm{h})$, which was achieved during the profiling of the cess that had no vegetation. The hydrocarbon emission of $28.2 \mathrm{~g} / \mathrm{h}$ was observed during the engine start-up and warmup. The lowest emission was recorded for the self-propelled drive with the hydraulic system turned off.

During the main track works, the $\mathrm{NO}_{\mathrm{x}}$ emissions increased, which was caused by the higher exhaust gas temperature (Figure 11). While profiling the ballast cess section of the track covered with small trees, the hourly nitrogen oxides emission value was $276.9 \mathrm{~g} / \mathrm{h}$. The lowest concentration of nitrogen oxide in the exhaust gas was recorded while travelling between locations as well as during engine start-up and heating. Each of these test sections were characterized by a lower engine load.

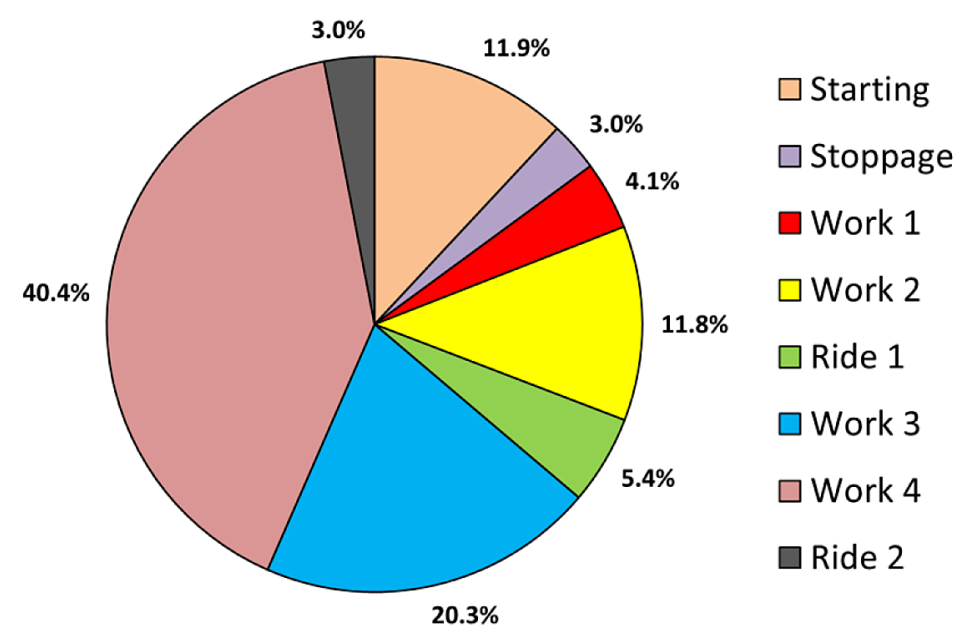

Figure 8. Share of individual activities in the entire work cycle in the test duration of the PŁT-500 railway subgrader 
In the vehicles equipped with internal combustion engines, the $\mathrm{CO}_{2}$ emissions are known to be closely correlated with the fuel consumption values. As in the case of nitrogen oxides, the highest carbon dioxide emissions were recorded for the activities related to track works (Figure 12). Similarly, the lowest $\mathrm{CO}_{2}$ values were recorded for travel sections and the engine start-up

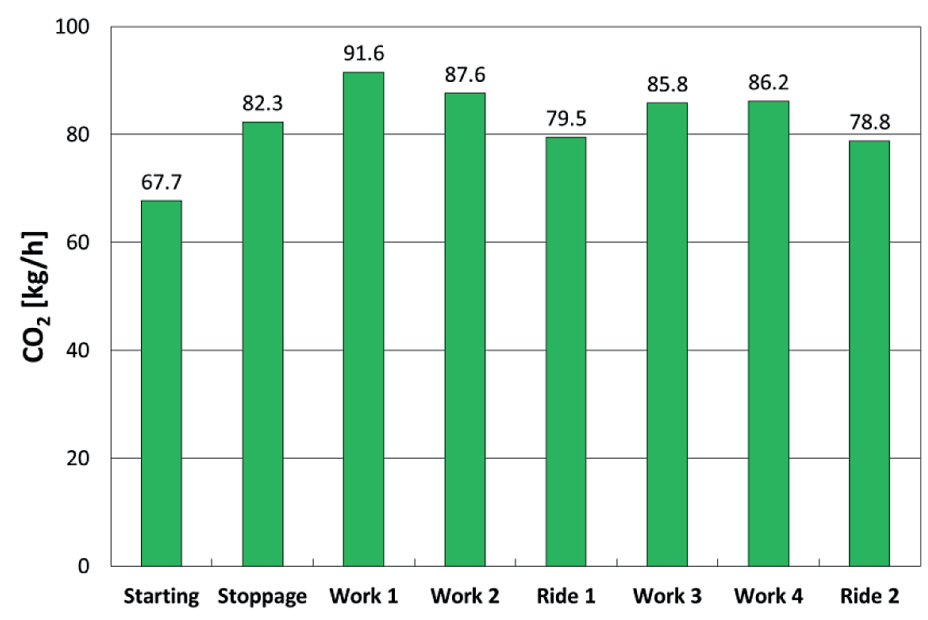

Figure 9. Hourly emission of $\mathrm{CO}$ for each of the test work sections

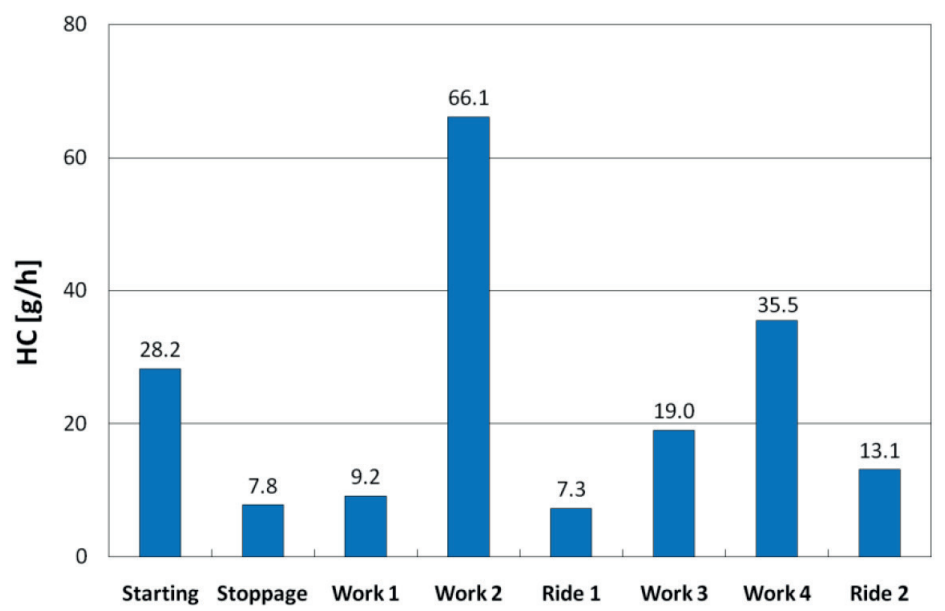

Figure 10. Hourly emission of $\mathrm{CO}_{2}$ for each of the test work sections

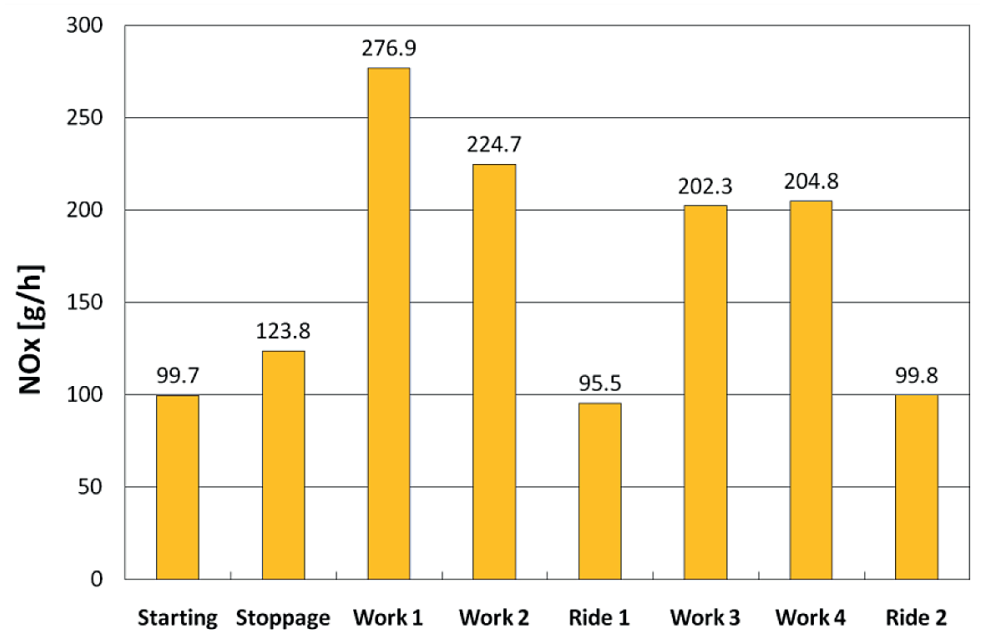

Figure 11. Hourly emission of $\mathrm{HC}$ for each of the test work sections 


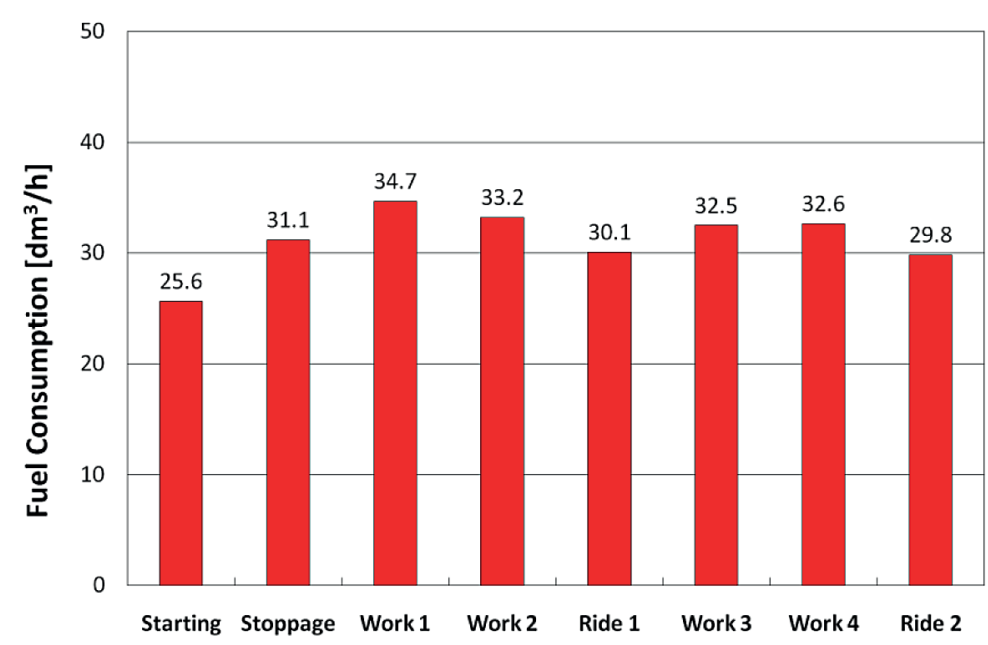

Figure 12. Hourly emission of $\mathrm{NO}_{\mathrm{x}}$ for each of the test work sections

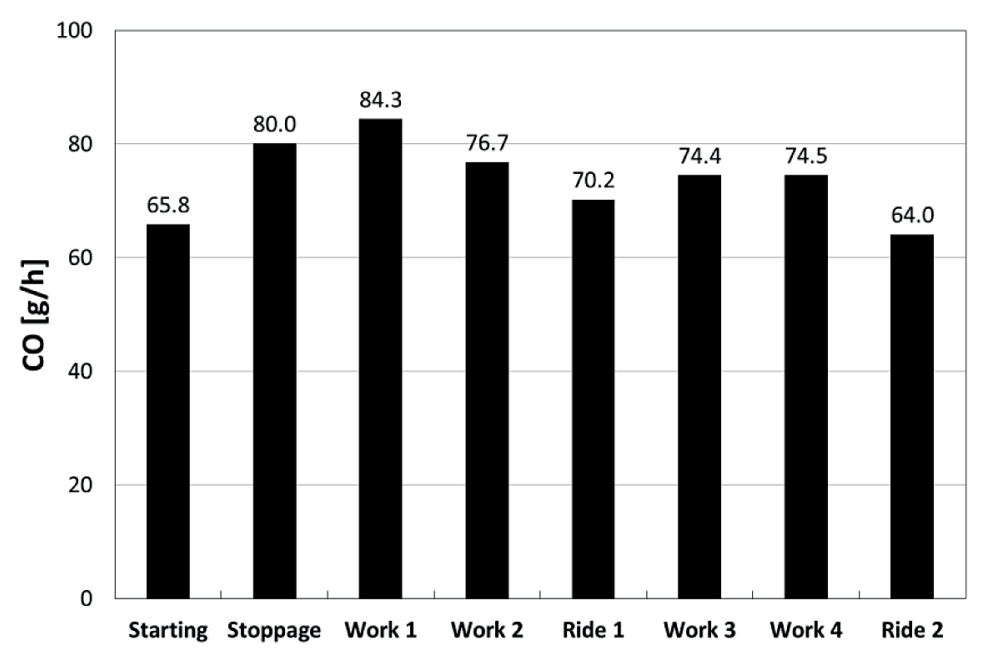

Figure 13. Fuel consumed per hour for each of the test work sections

period (Figure 13). The fuel consumption during the performed activities fluctuated in the range from $32 \mathrm{dm}^{3} / \mathrm{h}$ to $35 \mathrm{dm}^{3} / \mathrm{h}$. At the time of starting the engine, hourly fuel consumption was at its lowest value $\left(25.6 \mathrm{dm}^{3} / \mathrm{h}\right)$.

\section{CONCLUSIONS}

The analyses performed in the article allowed estimating the level of exhaust emissions and fuel consumption for the PŁT-500 railway subgrader machine as measured in real operation. The measurement method was characterized by recording the operating data under transient conditions.

Performing track maintenance operations was found to be characterized by a large share of idling, resulting from the specific nature of the machine operation. This can be explained by the occurrence of multiple long stops with the engine running in idle. For this reason the efficiency of operating track maintenance machines tends to be low. Therefore, it becomes necessary to carry out the activities aimed at increasing the overall operating efficiency of specialized track machines. To this end, future research will be focused on organizational and technical measures that could be employed to increase the vehicle efficiency and reduce fuel consumption. A specific emission and energy balance is expected to be produced, which would then be used to develop appropriate operational guidelines for the operators and users of the PŁT-500 railway subgrader.

\section{REFERENCES}

1. Alireza A., F. Corman, and G. Lodewijks, 2017. Condition monitoring approaches for the detection of railway wheel defects. Proceedings of the 
Institution of Mechanical Engineers, Part F: Journal of Rail and Rapid Transit 231.8, 961-981.

2. Gómez M.J., C. Castejón, E. Corral and J.C. 2020. García-Prada, Railway Axle Condition Monitoring Technique Based on Wavelet Packet Transform Features and Support Vector Machines. Sensors 20.12, 3575 .

3. Vinberg E., M. Martin, A.H. Firdaus, Y. Tang, and A. Qazizadeh, 2018. Railway applications of condition monitoring. KTH Royal Institute of Technology: Stockholm, Sweden.

4. Entezami M., C. Roberts, P. Weston, E. Stewart, A. Amini, and M. Papaelias, 2020. Perspectives on railway axle bearing condition monitoring. Proceedings of the Institution of Mechanical Engineers, Part F: Journal of Rail and Rapid Transit 234.1, 17-31.

5. Kampczyk A., 2020. Magnetic-Measuring Square in the Measurement of the Circular Curve of Rail Transport Tracks. Sensors 20.2, pp. 560.

6. Consilvio A., J. Solís-Hernández, N. JiménezRedondo, P. Sanetti, F. Papa, and I. MingolarraGaraizar, 2020. On Applying Machine Learning and Simulative Approaches to Railway Asset Management: The Earthworks and Track Circuits Case Studies. Sustainability 12.6, 2544.

7. Gibert X., V.M. Patel and R. Chellappa, 2016. Deep multitask learning for railway track inspection. IEEE transactions on intelligent transportation systems 18.1, 153-164.

8. Railway traffic safety report - 2019-Office of Rail Transport. 2019.

9. Szadkowski P., 2019. Modern approach to planning and execution of railway construction works. Zeszyty Naukowo-Techniczne Stowarzyszenia Inżynierów i Techników Komunikacji w Krakowie. Seria: Materiały Konferencyjne.

10. Kędra Z., 2017. echnologia robót torowych. Gdańsk University of Technology, 2017.

11. Rolling stock potential, Trends and forecasts. Office of Rail Transport.

12. Andrzejewski M., P. Daszkiewicz, Ł. Rymaniak, J. Merkisz, and M. Kamińska, 2018. Impact of modernization of locomotives operated in Poland on the emission of toxic compounds in exhaust gases. AUTOBUSY-Technika, Eksploatacja, Systemy Transportowe 19.12, 54-57.

13. Rymaniak Ł., P. Lijewski, M. Kamińska, P. Fuć, B. Kurc, M. Siedlecki, T. Kalociński and A. Jagielski, 2020. The role of real power output from farm tractor engines in determining their environmental performance in actual operating conditions. Computers and Electronics in Agriculture 173, 105405.
14. Bielaczyc P., J. Merkisz, J. Pielecha and J. Woodburn, 2018. A comparison of gaseous emissions from a hybrid vehicle and a non-hybrid vehicle under real driving conditions. No. 2018-01-1272. SAE Technical Paper.

15. Gis W., M. Gis and J. Pielecha, 2020. Comparative Studies of Exhaust Emissions from Three City Buses in Real Traffic Conditions, One with LNG, the Other with CI Engine and a Hybrid Bus. No. 2020-01-2191. SAE Technical Paper.

16. Bielaczyc P., J. Merkisz, J. Pielecha and J. Woodburn, 2020. RDE-Compliant PEMS Testing of a Gasoline Euro 6d-TEMP Passenger Car at Two Ambient Temperatures with a Focus on the Cold Start Effect. No. 2020-01-0379. SAE Technical Paper.

17. Rymaniak Ł., P. Fuć, P. Lijewski, M. Kamińska, P. Daszkiewicz, and A. Ziółkowski, 2019. Evaluating the environmental costs in Poland of city buses meeting the Euro VI norm based on tests in real operating conditions. Archives of Transport 52.

18. Lijewski P., M. Kozak, P. Fuć, Ł. Rymaniak and A. Ziółkowski, 2020. Exhaust emissions generated under actual operating conditions from a hybrid vehicle and an electric one fitted with a range extender. Transportation Research Part D: Transport and Environment 78, 102183.

19. Pigłowska M., B. Kurc, Ł. Rymaniak, P. Lijewski and P. Fuć, Kinetics and Thermodynamics of Thermal Degradation of Different Starches and Estimation the $\mathrm{OH}$ Group and $\mathrm{H}_{2} \mathrm{O}$ Content on the Surface by TG/DTG-DTA.” Polymers 12.2, 2020, 357.

20. Bajerlein M., L. Rymaniak, P. Swiatek, A. Ziolkowski, P. Daszkiewicz and M. Dobrzynski, 2014. Modification of a hybrid city bus powertrain in the aspect of lower fuel consumption and exhaust emissions. Applied Mechanics and Materials. Vol. 518. Trans Tech Publications Ltd.

21. Pielecha I., J. Merkisz, M. Andrzejewski, P. Daszkiewicz, R. Swiechowicz and M. Nowak, 2019. Ultracapacitors and fuel cells in rail vehicle drive systems. Rail Vehicles, 2, 9-19.

22. Beltiukov V., A. Andreev and A. Sennikova, 2020. Analysis of Changes of Track Upper Structure Technical Condition and Its Operation Costs in Regions with Long Winter Period for Different Types of Rail Fastenings. Transportation Soil Engineering in Cold Regions, vol. 1. Springer, Singapore, 265-274.

23. Materials of Przedsiębiorstwo Robót Torowych „TORREMS”. Internet website: www.torrems.pl

24. Materials of Google Maps. Internet website: www. google.pl/maps 